\title{
Studies on Insect Diversity Associated with Important Tree Species at Bhubaneswar, Odisha, India
}

\author{
M. K. Tripathy, B. Dandapat* and Nalini Kumar Panda \\ College of Forestry OUAT, Bhubaneswar, India \\ *Corresponding author
}

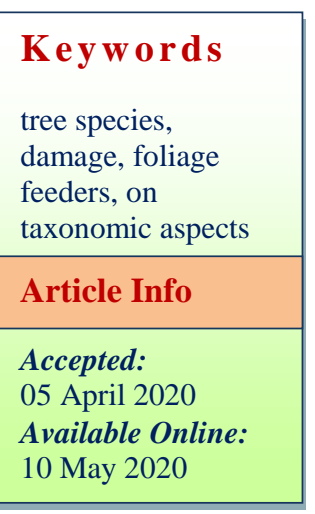

\section{A B S T R A C T}

A field experiment was conducted in nearby areas of Bhubaneswar to document the insect pests associated with some important tree species used for avenue plantations. The species taken for study are Gambhar (Gmelina arborea, Verbenaceae), Kadam (Neolamarkia cadamba), Mahogany, (Swetnia macrophylla) Kangada (Xylia xylocarpa Fabaceae)and Spanish cherry(Mimosups elengi, Sapotaceae). A total of 50 numbers of insect pests have been recorded. While categorizing the recorded insects based upon their mode of damage, foliage feeders are found as the dominant groups comprising more than $50 \%$ of total recorded insect pests followed by sap feeders $(22 \%)$. The bark feeders like termite and Inderbela comprises the third largest group (16.0\%) in the studied location. While categorizing the available insects on taxonomic aspects. Lepidepterous insects are found as pioneer among all comprising of $34 \%$ of the total followed by the sap feeders belonging to hemiptera. (22\%). Coleopterous insects occupies the third positioned with $12 \%$ share of the total recorded species Among plant species Kadam recorded highest Lepidepterous diversity $(66.6 \%)$ followed by Gambhar (30.00\%). Orthopteran population including grasshoppers and crickets were more recorded in Mahogany $(57.14 \%)$ followed by Mimusops.

\section{Introduction}

Out of the total forest area of $32 \%$ in the state, most part is under potential threat to anthropogenic activities causing reduction in species diversity (Hussain \& Tripathy, 2016). Besides several biotic and abiotic factors are also poses serious threat to both afforested and natural plantations causing great loss to the freshly transplanted stand of several important timber yielding species. Continuous and severe outbreaks of several pests are found to be associated with loss of precious species in both natural forests and avenue plantations.

The report on insect-pest incidence, beneficial arthropods association in most of the important tree species in the country is quite meager. In spite of lot of scope for using biocontrol agents in such permanent ecosystems, the work done in these regard is 
quite inadequate because of lacking appropriate sampling techniques to monitor pest and bio control activities.

Hence, in the present investigation an attempt is being taken to produce a systematic documentation regarding the list of insects associated with few important afforested and avenue plantation species popularly used throughout the state. The species teken for study are Gambhar (Gmelina arborea, Verbenaceae), Kadam (Neolamarkia cadamba), Mahogany, (Swetnia macrophylla) Kangada (Xylia xylocarpa Fabaceae) and Spanish cherry (Mimosups elengi, Sapotaceae). Such attempt may be helpful in future in formulating IPM strategy as per feasibility and warranty of situation.

\section{Materials and Methods}

Abundance of insects were recorded from 3 different locations of Bhubaneswar during first fortnight July, 2017 to Aug 2018. Bhubaneswar is situated at an elevation of $25.9 \mathrm{~m}$ above mean sea level at $20^{\circ} 15^{\prime} \mathrm{N}$ latitude and $85^{\circ} 52^{\prime} \mathrm{E}$ longitude. It is situated in the East \& South East Coastal Plain zone of Odisha, which falls under Tropical wet-dry or Tropical Savanna forest type. Flying and slow moving insects were collected by means of a swift net and preserved appropriately.

Immature stages of Lepidopterous and Coleopterous insects were reared in the post graduate laboratory of college of Forestry up to the adult stage in natural food medium in plastic cups of 4 inch diameter and 4 inch depth after following all the sanitation practices. Identification was established either by personnel experience or from Entomology museum or by consulting professors of Entomology department or from Internet sources or by using standard keys lay by established workers. (Patil et al., 2016, Tripathy et al., 2018) Specimens were preserved by following appropriate technique in case of delay in identification. At different locations, trees showing uniform growth pattern and age were selected, plants were divided into 3 categories such as (i) Seedlings (ii) Plants- 1-3 year old (Saplings)(iii) Plantsmore than 3 years old.(Pandey et al., 2010, Tripathy et al., 2018) For saplings, ten number of saplings and ten terminal twigs/sapling were randomly selected and from more than three years plants five plants were selected and 10 no of twigs were selected from lower, middle and upper canopy, from which all leaves were sampled for observing the presence of grubs or adults of defoliator/standard branch.

\section{Results and Discussion}

A total of 50 number of insect pests have been recorded to infest these species during the experimental period at different growth stages viz. seedlings, saplings and full grown stages at Bhubaneswar situation which has been summarized in Table1. Gambhar is a multipurpose and fast growing timber species and has a problem of multiple insect pest attack in India. Several workers has observed 101 insect pests infesting to Gmelina arborea from India (Nair, 2007) Mathur and Singh (1959) recorded 21 defoliators and 13 shoot borers infesting to this plant species but Calopepla leayana and Tingis beesoni was found as most destructive. This fact was agreed by several workers like, Aung Zeya 1981, 1983, Nair and Mathew 1988, Meshram et al., 2001; Mathur 1979; Ahmad and SenSharma. 1990, Burman 2014 etc. Meshram et al., 2001 from India also viewed Calypepla leyana as the most damaging one. The present study also corroborate the same fact that Calopepla leayana is the major defoliator of this species recorded here during the period of experimentation with defoliation recorded from seedlings to saplings and also in full grown plants. 
Table.1 Succession of different insect pests associated with important tree species during the observation period at Bhubaneswar (2017-2018)

\begin{tabular}{|c|c|c|c|c|c|c|}
\hline \multicolumn{7}{|c|}{ Gambhar - Gmelina arboria ,Roxb: Verbenaceae } \\
\hline $\begin{array}{l}\text { Sl. } \\
\text { No. }\end{array}$ & $\begin{array}{l}\text { Pest Common } \\
\text { name }\end{array}$ & Scientific name & Order & Family & category & Status \\
\hline 1 & $\begin{array}{l}\text { Gambhar } \\
\text { defoliator }\end{array}$ & $\begin{array}{l}\text { Calypepla } \\
\text { leyana((Latreille) }\end{array}$ & Coleoptera & Chrysometidae & $\begin{array}{l}\text { Foliage } \\
\text { feeder }\end{array}$ & $\begin{array}{l}\text { Major in } \\
\text { seedling and } \\
\text { pole sized plants }\end{array}$ \\
\hline 2 & $\begin{array}{l}\text { Gambhar shoot } \\
\text { weevil }\end{array}$ & Alcidodes ludificator & Coleoptera & Curculionidae & $\begin{array}{l}\text { Shoot } \\
\text { borer }\end{array}$ & Major in tree \\
\hline 3 & $\begin{array}{l}\text { Brown winged } \\
\text { Grasshopper }\end{array}$ & Arphia conspersa & Orthoptera & Acrididae & $\begin{array}{l}\text { Foliage } \\
\text { feeder }\end{array}$ & $\begin{array}{l}\text { Major in } \\
\text { seedlings }\end{array}$ \\
\hline 4 & Mealy bug & $\begin{array}{l}\text { Pseudococcus } \\
\text { filamentosus }\end{array}$ & Hemiptera & Pseudococcidae & Sap sucker & $\begin{array}{l}\text { Attacks leaves } \\
\text { and young } \\
\text { shoots }\end{array}$ \\
\hline 5 & Mealy bug & Nipaecoccus viridis & Hemiptera & Pseudococcidae & Sap sucker & $\begin{array}{l}\text { Attack young } \\
\text { leaves and } \\
\text { shoots }\end{array}$ \\
\hline 6 & Mealy bug & Planococcus citri & Hemiptera & Pseudococcidae & Sap sucker & $\begin{array}{l}\text { Attack young } \\
\text { leaves and } \\
\text { shoots }\end{array}$ \\
\hline 7 & $\begin{array}{l}\text { Gambhar leaf } \\
\text { miner }\end{array}$ & $\begin{array}{l}\text { Phyllocnistis } \\
\text { amydropa }\end{array}$ & Lepidoptera & Gracillaridae & Eat leaves & $\begin{array}{l}\text { tissues Attack } \\
\text { leaves }\end{array}$ \\
\hline 8 & Semilooper & Ectropis bhurmitra & Lepidoptera & Geometridae & Miner & Attack leaves \\
\hline 9 & Termite & Odentotermus obesus & Isoptera & Termitidae & $\begin{array}{l}\text { Rood } \\
\text { feeder and } \\
\text { bark feeder }\end{array}$ & Major in trees. \\
\hline 10 & Termite & Microtermus obesi & Isoptera & Termitidae & $\begin{array}{l}\text { Root and } \\
\text { bark feeder }\end{array}$ & Major in trees \\
\hline 11 & Bark borer & $\begin{array}{l}\text { Inderbela } \\
\text { quadrnotata }\end{array}$ & Lepidoptera & Arbellidae & Bark borer & Major in trees \\
\hline 12 & Tortoise beetle & $\begin{array}{l}\text { Aspidomorpha } \\
\text { miliaris }\end{array}$ & Coleoptera & Chrysomelidae & Miner & $\begin{array}{l}\text { Major in trees } \\
\text { but seasonal } \\
\text { appearance }\end{array}$ \\
\hline 13 & Leaf folder & Belippa laleana & Lepidoptera & Limacodidae & $\begin{array}{l}\text { Foliage } \\
\text { feeder }\end{array}$ & $\begin{array}{l}\text { Major but } \\
\text { seasonal }\end{array}$ \\
\hline 14 & Spittle bug & Poophilus costalis & Hemiptera & Aphrophoridae & Sapfeeder & Minor \\
\hline 15 & Aphids & Aphis gossypi & Hemiptera & Aphididae & Sap feeder & $\begin{array}{l}\text { Minor and } \\
\text { occasional }\end{array}$ \\
\hline 16 & White flies & $\begin{array}{l}\text { Aleuropapillatus } \\
\text { gmelinae }\end{array}$ & Hemiptera & Alyrodidae & Sap feeder & $\begin{array}{l}\text { Minor and } \\
\text { occasional }\end{array}$ \\
\hline 17 & Jassids & Unidentified & Hemiptera & Cicadellidae & Sap feeders & $\begin{array}{l}\text { Minor and } \\
\text { occasional }\end{array}$ \\
\hline 18 & Defoliating & Eupterote geminate & Lepidoptera & Eupterotidae & Foliage & Major in rainy \\
\hline
\end{tabular}




\begin{tabular}{|c|c|c|c|c|c|c|}
\hline & caterpillar & & & & feeders & season \\
\hline 19 & $\begin{array}{l}\text { Bark eating } \\
\text { caterpillar }\end{array}$ & $\begin{array}{l}\text { Inderbella } \\
\text { quadrinotata }\end{array}$ & Lepidoptera & Arbellidae & $\begin{array}{l}\text { Bark } \\
\text { feeder }\end{array}$ & $\begin{array}{l}\text { Major in } \\
\text { problematic } \\
\text { areas }\end{array}$ \\
\hline 20 & Defoliating beetle & Unidentified & Coleoptera & ---- & $\begin{array}{l}\text { Foliage } \\
\text { feeder }\end{array}$ & $\begin{array}{l}\text { Minor, during } \\
\text { rainy seasons }\end{array}$ \\
\hline \multicolumn{7}{|c|}{ Kadamba - Neolamarkia cadamba Roxb, family : Rubiaceae } \\
\hline 1 & Leaf defoliater & $\begin{array}{l}\text { Arthroschista } \\
\text { hilalaris }\end{array}$ & Lepidoptera & Pyralidae & $\begin{array}{l}\text { Foliage } \\
\text { feeder }\end{array}$ & $\begin{array}{l}\text { Pole size and } \\
\text { larger plants }\end{array}$ \\
\hline 2 & Semi looper & Ectropis bhurmitra & Lepidoptera & Geometridae & $\begin{array}{l}\text { Foliage } \\
\text { feeder }\end{array}$ & Attack leaves \\
\hline 3 & Bark borer & $\begin{array}{l}\text { Inderbela } \\
\text { quadrinotata }\end{array}$ & Lepidoptera & Arbillidae & $\begin{array}{l}\text { Bark } \\
\text { feeder }\end{array}$ & Major in tree \\
\hline 4 & $\begin{array}{l}\text { Brown grass } \\
\text { hopper }\end{array}$ & Arphia conspersa & Orthoptera & Acrididae & Leaf feeder & $\begin{array}{l}\text { Major in } \\
\text { seedlings }\end{array}$ \\
\hline 5 & Bag worm & Pteroma plagiophleps & Lepidoptera & Psychidae & Leaf feede & Minor in plants \\
\hline 6 & Beetle & Unidentified & Coleoptera & & $\begin{array}{l}\text { Available } \\
\text { in bark }\end{array}$ & $\begin{array}{l}\text { Visitor and dead } \\
\text { wood feeder }\end{array}$ \\
\hline 7 & Frog hopper & Unidentified & Homoptera & Fulgoridae & $\begin{array}{l}\text { Sap } \\
\text { suckers } \\
\text { from } \\
\text { leaves }\end{array}$ & $\begin{array}{l}\text { Appeared in } \\
\text { rainy season }\end{array}$ \\
\hline 8 & Caterpillar - & Unidentified & Lepidoptera & ----- & $\begin{array}{l}\text { Foliage } \\
\text { feeder }\end{array}$ & $\begin{array}{l}\text { Appeared during } \\
\text { rainy season }\end{array}$ \\
\hline 9 & Leaf minor & Unidentified & Lepidoptera - & ------ & $\begin{array}{l}\text { Foliage } \\
\text { feeder }\end{array}$ & $\begin{array}{l}\text { Minor during } \\
\text { rainy season }\end{array}$ \\
\hline \multicolumn{7}{|c|}{ Mehagani- Swetenia macrophyla King: Meliaceae } \\
\hline 1 & $\begin{array}{l}\text { Brown } \\
\text { grasshopper }\end{array}$ & Arphia conspersa & Orthoptera & Acrididae & Leaf feeder & $\begin{array}{l}\text { Major in } \\
\text { Seedling }\end{array}$ \\
\hline 2 & Semi looper & Ectropis bhurmitra & Lepidoptera & Geometridae & $\begin{array}{l}\text { Foliage } \\
\text { feeder }\end{array}$ & Seedling \\
\hline 3 & Shoot borer & Hypsipyla robusta & Lepidoptera & Pyralidae & $\begin{array}{l}\text { Top shoot } \\
\text { borring }\end{array}$ & $\begin{array}{l}\text { Major during } \\
\text { post rainy and } \\
\text { winter season in } \\
\text { seedlings and } \\
\text { pole sized plants }\end{array}$ \\
\hline 4 & $\begin{array}{l}\text { Brown grass } \\
\text { hopper (sp.2) }\end{array}$ & $\begin{array}{l}\text { Diabolocatantops } \\
\text { pinguis }\end{array}$ & Orthoptera & Acrididae & Leaf feeder & $\begin{array}{l}\text { Major in } \\
\text { seedlings }\end{array}$ \\
\hline 5 & Cricket & $\begin{array}{l}\text { Brachytrupus } \\
\text { portentosus }\end{array}$ & Orthoptera & Gryllidae & Leaf feeder & $\begin{array}{l}\text { Major in } \\
\text { seedling }\end{array}$ \\
\hline 6 & Leaf footed bug & Unidentified & Hemiptera & Coreidae & Leaf feeder & Minor \\
\hline 7 & Grasshopper & Unidentified & Orthoptera & Acrididae & $\begin{array}{l}\text { Foliage } \\
\text { feeder }\end{array}$ & $\begin{array}{l}\text { Major in } \\
\text { seedling }\end{array}$ \\
\hline \multicolumn{7}{|c|}{ Spanish Cherry- Mimusops elengi Linn: Sopotaceae } \\
\hline 1 & Webber & $\begin{array}{l}\text { Nephopterix } \\
\text { eugraphila }\end{array}$ & Lepidoptera & Phycitidae & $\begin{array}{l}\text { foliage } \\
\text { feeder }\end{array}$ & $\begin{array}{l}\text { Appeared mainly } \\
\text { during rainy } \\
\text { season } \\
\text { Major in all } \\
\text { groups of plants }\end{array}$ \\
\hline
\end{tabular}




\begin{tabular}{|c|c|c|c|c|c|c|}
\hline 2 & Termites & $\begin{array}{l}\text { Odontotermus obesus } \\
\text { Microtermus obesi }\end{array}$ & Isoptera & Termitidae & $\begin{array}{l}\text { Bark } \\
\text { feeder }\end{array}$ & $\begin{array}{l}\text { Major in big } \\
\text { trees and } \\
\text { transplants }\end{array}$ \\
\hline 3 & Grass hoppers & Arphia conspersa & Orthoptera & Acrididae & Leaf feeder & $\begin{array}{l}\text { Major in } \\
\text { seedlings }\end{array}$ \\
\hline 4 & Thrips & $\begin{array}{l}\text { Arrenothrips } \\
\text { ramkrishnae Hood }\end{array}$ & Thysanoptera & Thripidae & $\begin{array}{l}\text { foliage } \\
\text { feeder }\end{array}$ & $\begin{array}{l}\text { Appeared } \\
\text { throughout the } \\
\text { year.Major in all } \\
\text { plant groups }\end{array}$ \\
\hline 5 & Grasshoppers & $\begin{array}{l}\text { Diabolocatantops } \\
\text { pinguis }\end{array}$ & Orthoptera & Acrididae & $\begin{array}{l}\text { Foliage } \\
\text { feeder }\end{array}$ & $\begin{array}{l}\text { Appears } \\
\text { throughout the } \\
\text { year }\end{array}$ \\
\hline 6 & Mealybug & Unidentified & Hemiptera & Pseudococcidae & Sap feeder & $\begin{array}{l}\text { Appears in } \\
\text { winter }\end{array}$ \\
\hline 7 & $\begin{array}{l}\text { Tent hairy } \\
\text { catterpillar }\end{array}$ & Metanastia hyrtica & Lepidoptera & Lesiocampidae & Defoliator & $\begin{array}{l}\text { Appears during } \\
\text { rainy and winter }\end{array}$ \\
\hline \multicolumn{7}{|c|}{ Kangada-Xylia xylocarpaRoxb : Fabaceae } \\
\hline 1 & Bark feeder & $\begin{array}{l}\text { Inderbella } \\
\text { quadrinotata }\end{array}$ & Lepidoptera & Arbelidae & $\begin{array}{l}\text { Bark } \\
\text { feeder }\end{array}$ & $\begin{array}{l}\text { Major pest in } \\
\text { trees }\end{array}$ \\
\hline 2 & Grasshopper & Arphia conspersa & Orthoptera & Acrididae & Leaf feeder & $\begin{array}{l}\text { Major in } \\
\text { seedlings }\end{array}$ \\
\hline 3 & Termite & Odontotermus obesus & Isoptera & Termidae & $\begin{array}{l}\text { Bark } \\
\text { feeder }\end{array}$ & $\begin{array}{l}\text { Major in large } \\
\text { plants }\end{array}$ \\
\hline 4 & Termite & Microtermus obesi & Isoptera & Termidae & $\begin{array}{l}\text { Bark } \\
\text { feeder }\end{array}$ & $\begin{array}{l}\text { Major in large } \\
\text { plants }\end{array}$ \\
\hline 5 & Stink bug & Podisus brevispinus & Hemiptera & Pentatomidae & Sap feeder & $\begin{array}{l}\text { Major in large } \\
\text { plants }\end{array}$ \\
\hline 6 & Leaf footed bug & Unidentified & Hemiptera & Coreidae & Sap feeder & $\begin{array}{l}\text { Major in } \\
\text { seedlings }\end{array}$ \\
\hline
\end{tabular}

Table.2 Classification of insect pests into different categories of the observed species reported during study period at Bhubaneswar (2017-2018)

\begin{tabular}{|l|l|l|l|l|l|l|}
\hline & Mahogany & Xylia & Gambhar & Kadam & Mimusops & Total \\
\hline $\begin{array}{l}\text { Foliage } \\
\text { feeders }\end{array}$ & $5(71.42)$ & $1(16.6)$ & $9(42.8)$ & $6(66.6)$ & $5(71.42)$ & $26(52.00)$ \\
\hline Bark feeders & $1(14.28)$ & $2(33.3)$ & $2(9.52)$ & $2(22.2)$ & $1(14.28)$ & $8(16.00)$ \\
\hline Shoot borers & $1(14.28)$ & 0.00 & $1(4.76)$ & 0.00 & 0.00 & $2(4.00)$ \\
\hline Sap feeders & 0.00 & $2(33.3)$ & $7(33.3)$ & $1(11.1)$ & $1(14.28)$ & $11(22.00)$ \\
\hline Root feeders & 0.00 & 0.00 & $2(9.52)$ & 0.00 & 0.00 & $2(4.00)$ \\
\hline Wood feeder & 0.00 & $1(16.6)$ & 0.00 & 0.00 & 0.00 & $1(2.00)$ \\
\hline Total & $7(14.00)$ & $6(12.00)$ & $21(42.00)$ & $9(18.00)$ & $7(14.00)$ & $50(0.00)$ \\
\hline
\end{tabular}

Figures in parenthesis are percentage values 
Table.3 Classification of insect pest as per their taxonomic groups in the observed species during the study period at Bhubaneswar (2017-18)

\begin{tabular}{|l|l|l|l|l|l|l|}
\hline Insect orders & Gambhar & Kadam & Mahogany & Kangada & Baula & Total \\
\hline Coleoptera & $4(20)$ & $1(11.1)$ & 0.00 & $1(14.28)$ & 0.00 & $6(12)$ \\
\hline Lepidoptera & $6(30)$ & $6(66.6)$ & $2(28.57)$ & $1(14.28)$ & $2(28.57)$ & $17(34)$ \\
\hline Orthoptera & $1(5)$ & $1(11.1)$ & $4(57.14)$ & $1(14.28)$ & $2(28.57)$ & $9(18)$ \\
\hline Isoptera & $2(10)$ & 0.00 & 0.00 & $2(28.57)$ & $1(14.28)$ & $5(10)$ \\
\hline Hemiptera & $7(35)$ & 0.00 & $1(14.28)$ & $2(28.57)$ & $1(14.28)$ & $11(22)$ \\
\hline Others & 0.00 & $1(11.1)$ & 0.00 & 0.00 & $1(14.28)$ & $2(4)$ \\
\hline Total & $20(40)$ & $9(18)$ & $7(14)$ & $7(14)$ & $7(14)$ & $50(0.00)$ \\
\hline
\end{tabular}

Figures in parenthesis are percentage values

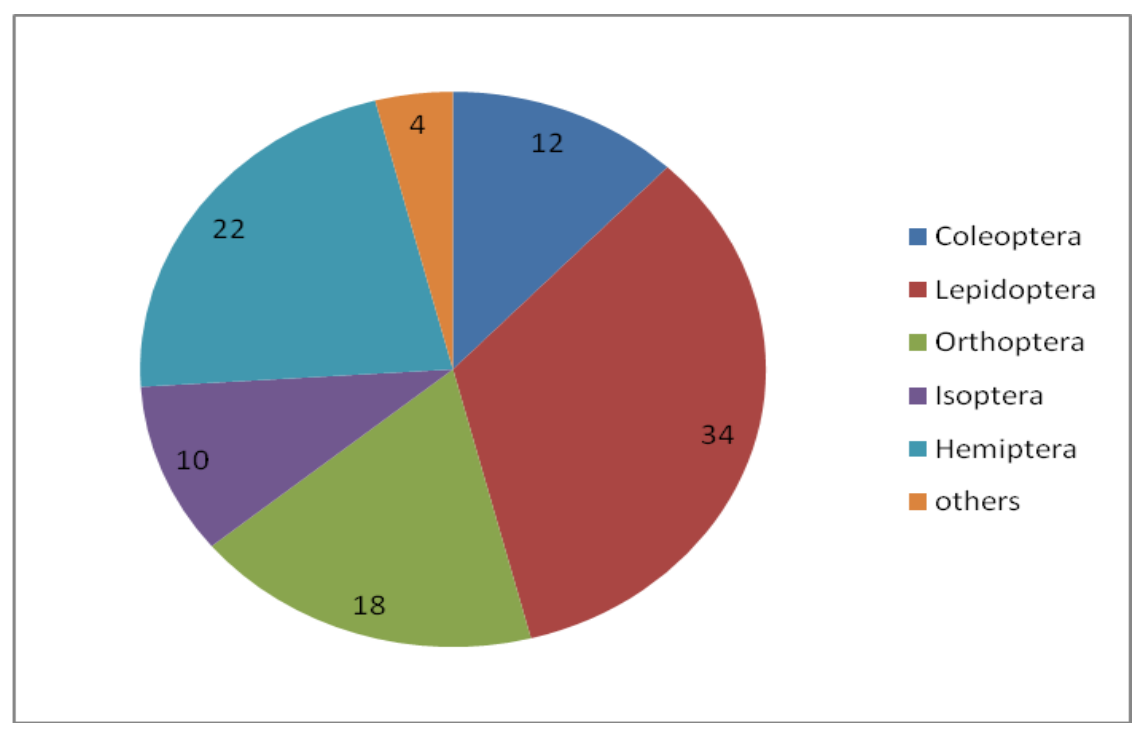

Fig.1 Order wise distribution of insect pests in the observed trees during the study period at Bhubaneswar (2017-18)

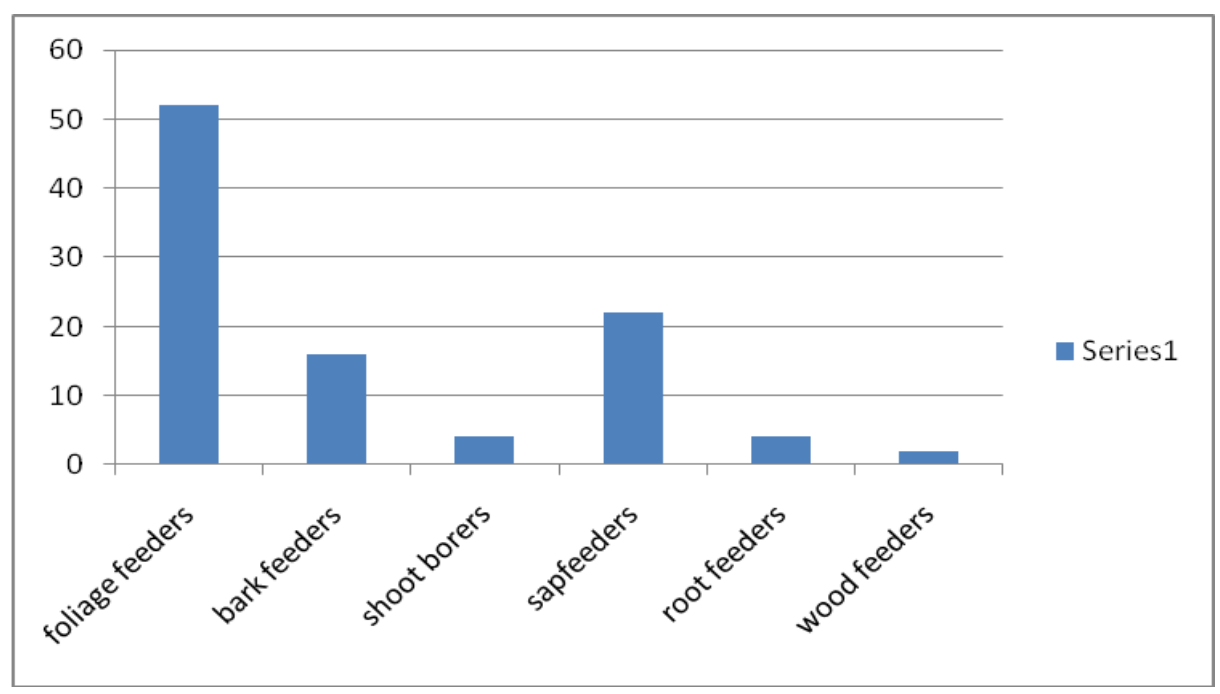

Fig.2 Classification of insect pests on the basis of damage in the observed species reported during period of experimentation at Bhubaneswar (2017-18) 

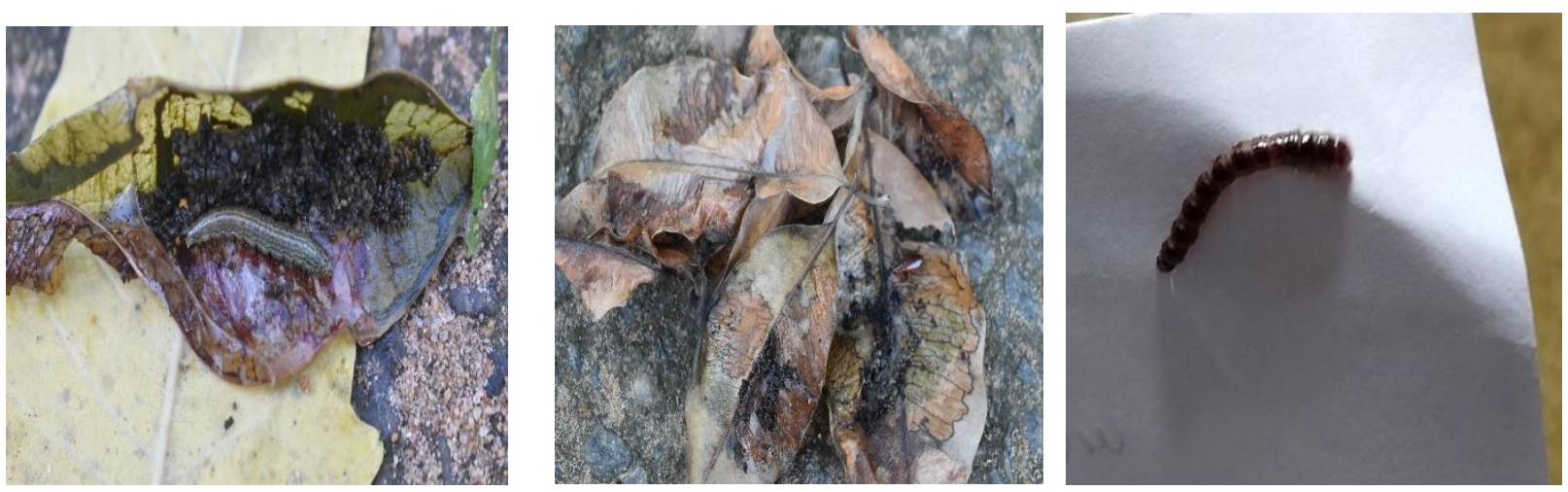

Mimosups webber infested twig

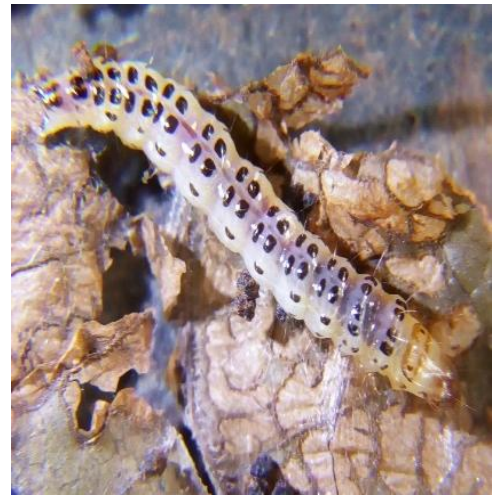

Kadam defoliator larvae

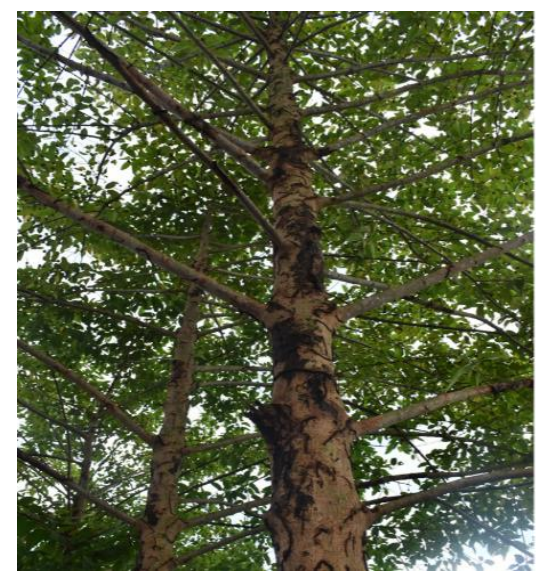

Inderbela infestation in kadam

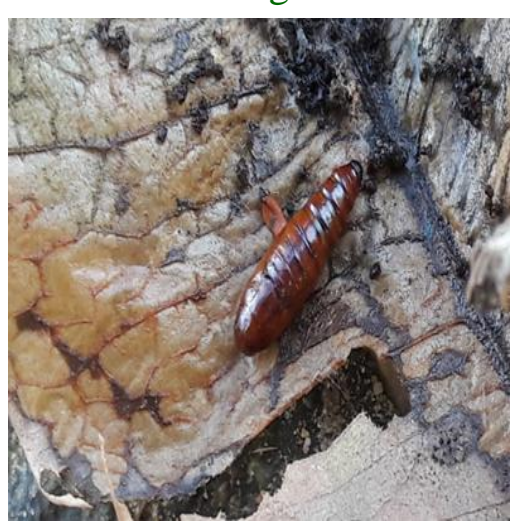

Kadam defoliator pupae

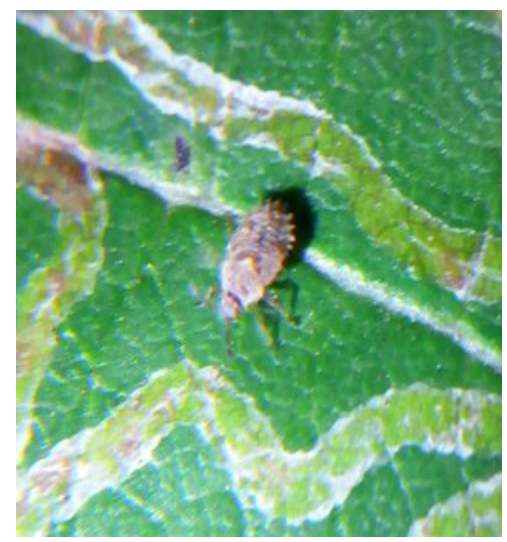

Leaf minor damage and

stink bug in kadm

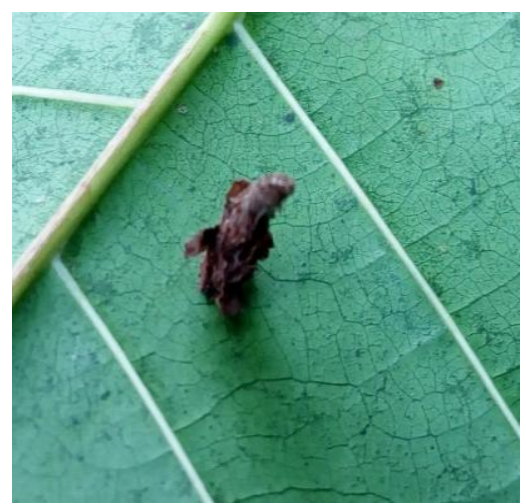

Bagworm larvae

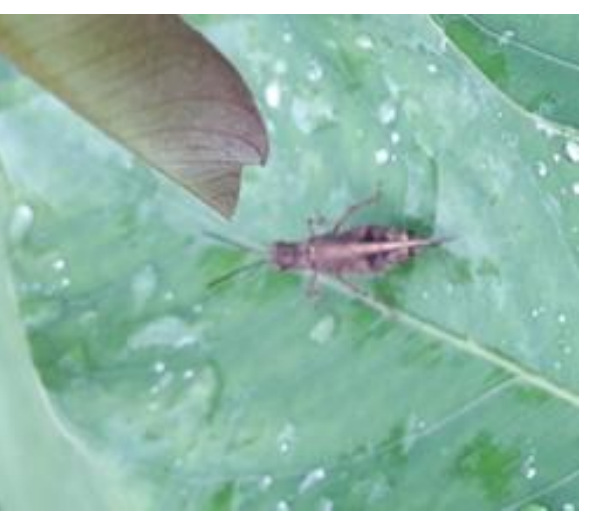



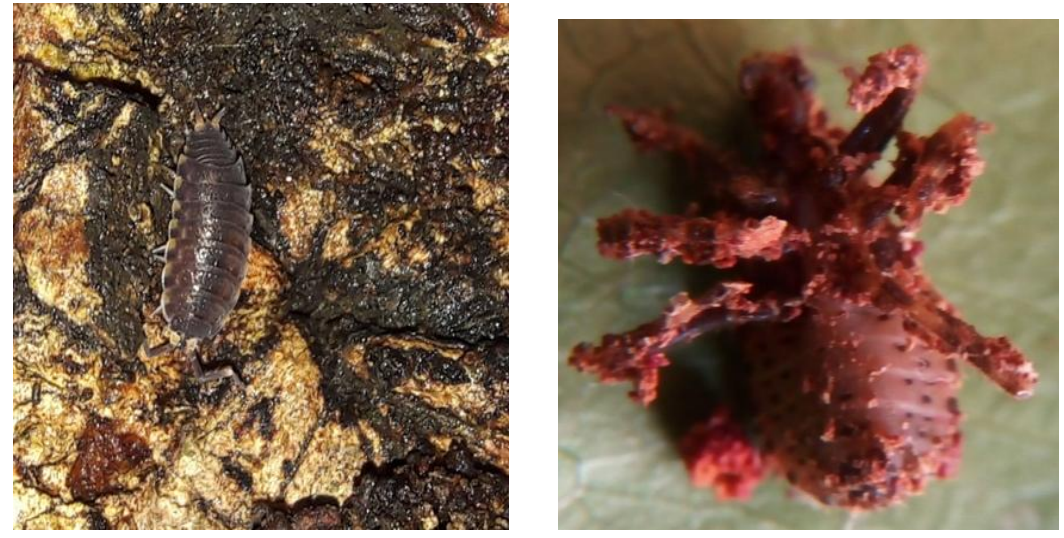

Pentatomid from xylia

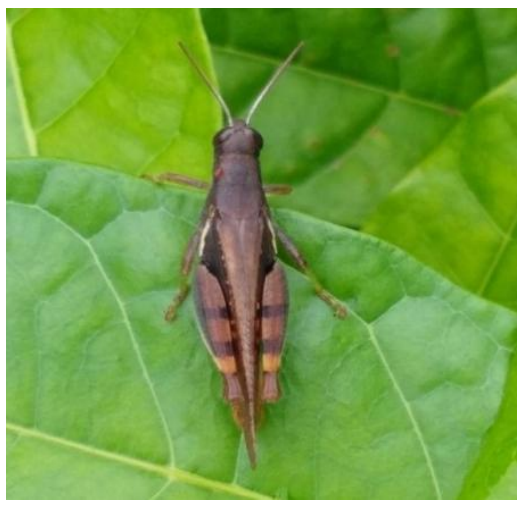

Brown grass hopper from xylia

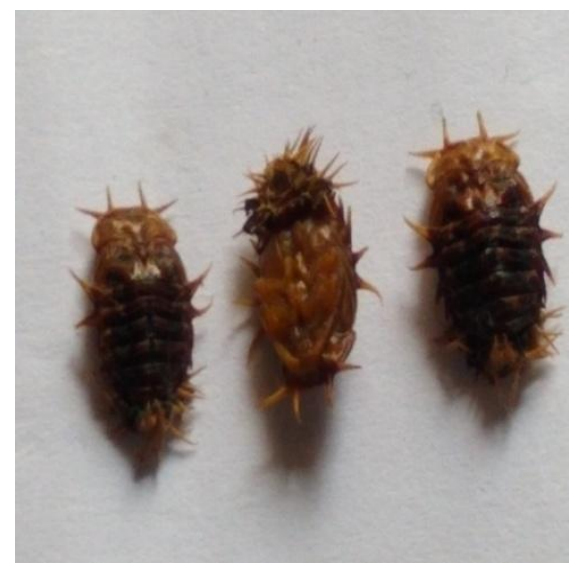

Pupae of calopepla

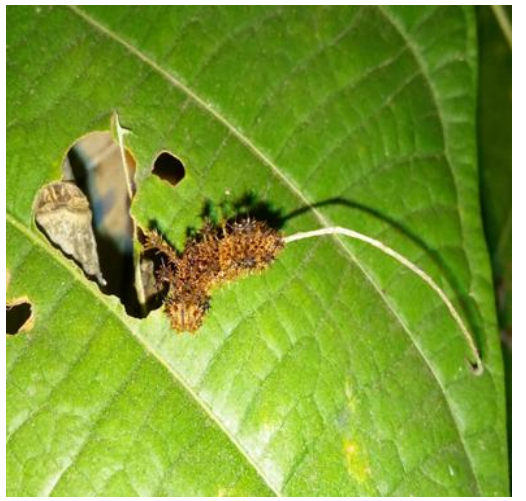

Unidentified caterpillar from kadam

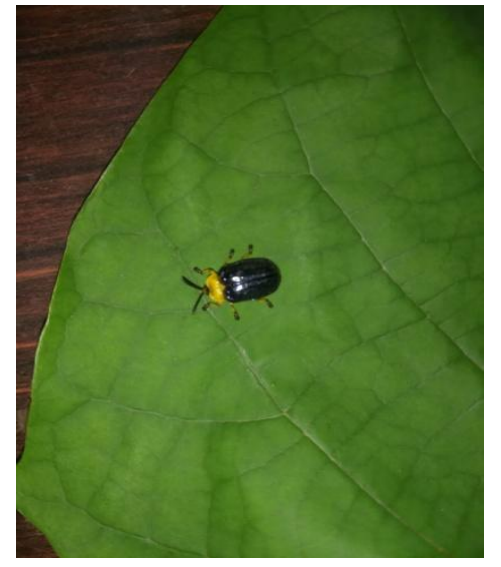

Adult of calopepla

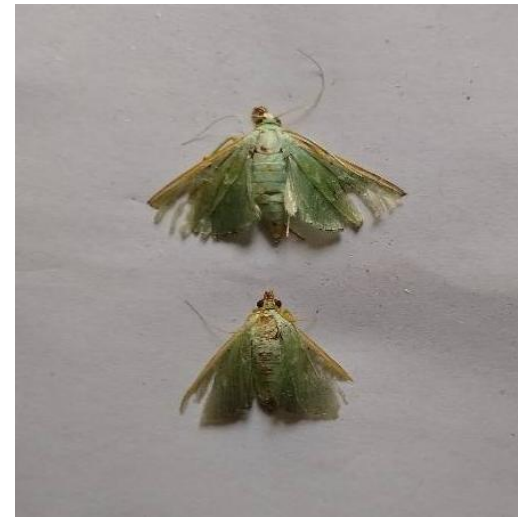

Female and male of kadam defoliator

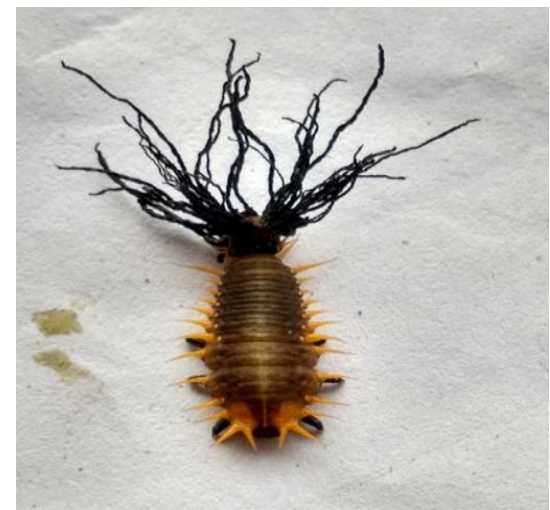

grubof calopepla

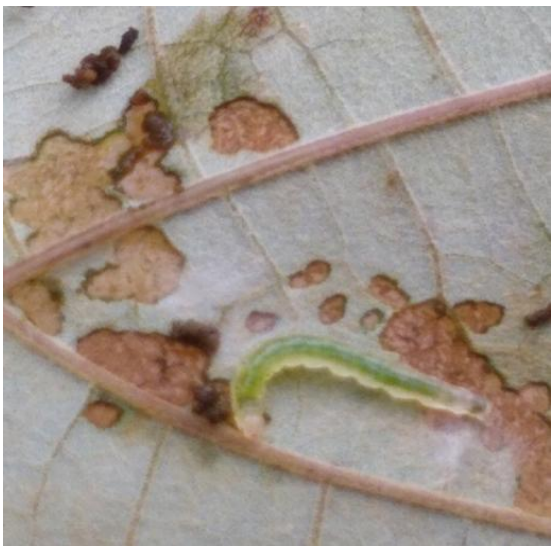

Folder in gambhar 


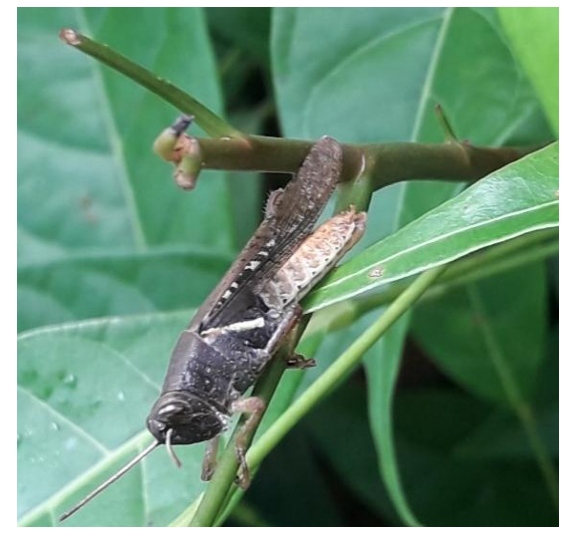

Grasshopper from xylia

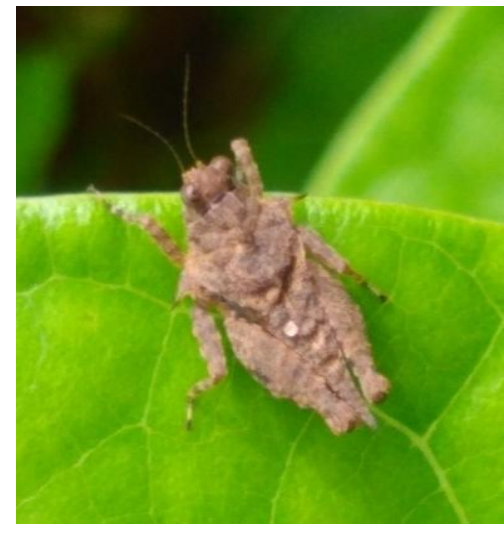

Grasshopper in mimosups

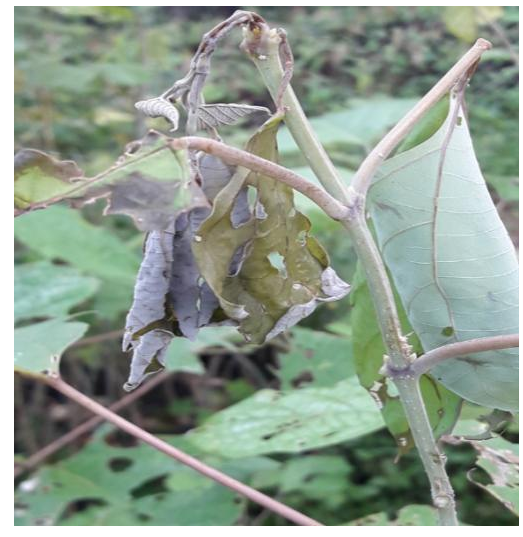

Damage of gambhar shoot weevil

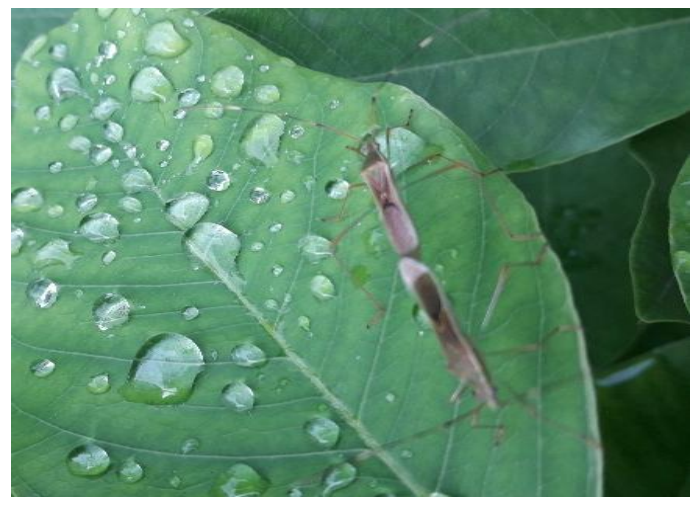

Coreid in xylia

Another important pest recorded here is Alcidodes ludificator which bores the shoot and kill the young plants and branches and the infestation was recorded throughout the year. In forest plants and trees suitable for plantation in agro forestry, because of height sampling becomes a great problem for which detection of distribution of insect pests at the uppermost canopy of large sized plants is not possible in a country like ours.

But in developed countries some other techniques like fogging and use of other sophisticated machineries has solved this problem. However, substantial loss of early transplants in the site and making the seedlings unsuitable for planting is the common outcome. Nair (2007) and Senthil Kumar and Murugasan (2012) from India viewed this shoot weevil as one of the minorpests attacking Gambhar. Reports from other countries regarding pest diversity of Gambhar is also available i.e. 20 in Thailand (Hutacharen, 1990). In a study on three year old plantation in Kerala, India, Nair and Mathew (1988) found the major damage was caused by 2 species of Insects i.e. Gambhar defoliator and Tingis beesoni and they reported a total of 34 species of insects to be associated with this tree. In Kadam the defoliator Arthorschista hilalaris is found as the major one appearing during the rainy and post rainy months. In the present study a total of 9 species were recorded from this species. Chey,2001 reported more than half a dozen species of defoliators in this species from Malaysia. Euteryste fabea (Lepidoptera: Eupterotidae) has been reported to cause 
substantial damage in this species from Phillipines (Quinones and Zamore. 1987). White grub damage in 1-2 year old seedlings in Indonesia is also reported (Intari and Natawaria. 1973) and the hepialid caterpillars (Sahyadrasus malabaricus) infesting the stems of saplings has been reported from Kerala, India (Nair, 1987).

Mahogany, the most preferred afforested species after teak in the state is observed to be infested by a total number of 7 species here at Bhubaneswar. The shoot borer Hypsipyla robusta attack is found as major one. Nair, 2007 also opined that less other insects are associated with the tree in exotic plantations of Mahogany, the dominant pest is one of the two species of Hypsipyla sp. Additional pests in native plantations include the mahogany web worm Macalla thyrsalis (Lepidoptera, Pyralidae) which webs the newly flushed leaves and feeds on them and Phyllocnistis meliacella (Lepidoptera, Gracillaridae) whose larvae mines in the leaves (Howard and Solis 1989). Termites are also considered important in this plant species as viewed by workers from India (Nair, 2007) and abroad (Mathew and Newton, 1998).

Mimusops elengi is a medicinal plant with typical leaf margin, lusture and dense foliage for which it is preferred at present for avenue plantations, plantation in public places including parks and backyards. At Bhubaneswar situation we have recorded 7 species of insects out of which the Phycitid borer Nephopteryx eugraphilla was the dominant one followed by thrips Arrenothrips ramkrishnae causing leaf galls. The literature in this regard is quite meager. Senthilkumar and Murugassan (2012) from Coimbatore reported its damaging status and host range in detail. However, the first species is a major concern during rainy season and the second one is available throughout the year in Bhubaneswar situation. Xylia xylocarpa was found to be resistant to any of the principal pests except bark feeder Inderbella quadrinotata (Arbellidae, Lepidoptera). But in seedlings, few insects are reported here and the total species infesting this plant at various growth stages are six in numbers. Workers like Mathew (1995) from Kerala also reported the same fact. As depicted in table 2and fig.2 while categorizing the recorded insects based upon their mode of damage, foliage feeders are the dominant groups comprising more than $50 \%$ of total recorded insect pests followed by sap feeders $(22 \%)$. The bark feeders like termite and Inderbella comprises the third largest group (16.0\%) in the studied location. While categorizing the available insects on taxonomic aspects (Table 3 and fig. 1 . Lepidepterous insects are found as pioneer among all comprising of $34 \%$ of all followed by the sap feeders belonging to hemipteran. (22\%). Coleopterous insects occupies the third positioned with $12 \%$ share of the total recorded species Among plant species Kadam recorded highest Lepidepterous diversity (66.6\%) followed by Gambhar $(30.00 \%)$. Orthopteran population including grasshoppers and crickets were more recorded in Mahogany $(57.14 \%)$ followed by Mimusops.

\section{References}

Ahmad SI and Sen-Sharma PK. 1990. Bionomics of Calopepla leayana latr. (Coleoptera: Chrysomelidae), a serious defoliator of Gmelina arborea Roxb. Plantations in India.

Indian forester, 116, 71-82.

Aung-Zeya. Two insect species doing derious damage to planted Yamane (Gmelina arborea) in Yazinand Moswe areas. Burma Forest Research Institute. Yazin Leaflet. 1981; 7: 80-81

Aung-Zeya. Further observation on Tingis beesoni (Hemiptera: Tingidae) incidence on Yamane(Gmelina 
arborea). Burma Forest Research Institute. Yazin Leaflet. 1983; 7: 82-83

Barman A. 2014. A brief perspective on Gmelina tree insect pest Craspedonta leayana. Journal of Entomology and Zoology Studies, 2(4): 276-278

Chery, V.K.(2001).The laran tree and its defoliators. The Planter, 77. 587-592

Howard, F.W. and Solis, M.A. 1989. Distribution, life history and host relationships of mahogany webworm, Macalla thyrsisalis (Lepidoptera: Pyralidae). Florida Entomologist, 72: 469-79

Hussain ,M .M. and Tripathy ,M.K. 2016. Prospects of IPM in forestry. Lead paper presented by Dr. M. K. Tripathy in national symposium on new horizons in pest management for sustainable developmental goals on 23-24 Dec at OUAT, BBSR 2016.pp 9-17(souvenir)

Hutacharen C. 1990. Forest insect pests in Thailand. In pest and diseases of forest plantations, ed. C. Hutacharern , K.G. MacDicken , M.H. Ivory and K.S.S. Nair. Bangkok: FAO regional Office for Asia and the Pacific, 75-79.

Intari ,S.E. and Natawaria, D. 1973. White grubs in forest tree nurseries and young plantations. Laporan lembaga penelitian Hutan, 167, 1-22.

Mathew ,J.E. and Newton, A.C. 1998. The Silviculture of Mahogany. Wallingford, Oxon: CAB International.

Mathew,G.(1995). Field performance of some indigenous tree species with respect to pest incidence in Kerala(India).Indian journal of Forestry, 18,133-40
Meshram ,P.B., Pande, P.K. and Banerjee, S.K. (2001). Impact of pest problems in Gmelina arborea Linn. Plantations in Western Maharastra, Indian forester, 127 (12), 1377-86.

Nair, K,S,S, and Mathew, G. 1988. Biology and control of fast growing hardwood species: Albezia falcataria and Gmelina arborea. KFRI Research Report No. 51. Kerala Forest Research Institute, Peechi, India.

Nair, K.S.S. 2007 Tropical forest insect pests: ecology, impact and management Cambridge University Press, Cambridge. 404.

Patil, S. S., Sutar, M.V .and Sathe ,T.V. 2016. Diversity, Biology and Control of insect pests of teak Tectona grandis from western Maharastra, Biolife, 4(1):141-146 Quiniones, S.S. and Zamora, R.A 1987. Forest Pests and Diseases in the Phillipines. In forest pests and diseases in Southeast Asia, BIOTROP Special publication No. 26, ed.E.D.de Guzman and ST Nuhamara. Bogor, Indonesia: Southeast Asian regional centre for tropical biology, 43-65.

Sethilkumar, and Murugesan. 2012. Insect pests of important trees species is south india and their management information. Technical bulletin by IFGTB , Coimbatore PP 1-12617

Tripathy ,M.K,Rout M and Tripathy 2018Population dynamics aof teak defoliator, Hyblaea puera

Cramer at Coastal Odisha „India .Journal of Entomology and Zoology studies 6(5) 2378-2387.

\section{How to cite this article:}

Tripathy. M. K., B. Dandapat and Nalini Kumar Panda. 2020. Studies on Insect Diversity Associated with Important Tree Species at Bhubaneswar, Odisha, India. Int.J.Curr.Microbiol.App.Sci. 9(05): 46-56. doi: https://doi.org/10.20546/ijcmas.2020.905.004 